\title{
Analisis Penerapan Protokol Kesehatan Masyarakat Bangkalan: dari Interpretasi Kulturalis-Religiusitas ke Implementasi "Teks Suci”
}

\author{
Masyhudunnury \\ Universitas Airlangga \\ Email: 2020@fisip.unair.ac.id
}

\begin{tabular}{ll}
\hline Keywords: & Abstract: \\
\hline "Teks Suci", & Over a year the COVID-19 pandemic has hit all corners of the world, including \\
Philosophy Studies, & remote areas throughout the archipelago. One of the reasons for the government's \\
Local Wisdom, & inopable efforts in dealing with it is that partial non-compliance has been poured in \\
Covid-19 & the form of regional legal products. This paper aims to analyze and explore the real \\
non-compliance of the community even though the local government has done its \\
utmost to make the community understand the purpose and noble purpose of the rule. \\
By using literature studies in analyzing empirical phenomena of behavior among the \\
people of Bangkalan district in response to the policy of 'state' in the face of \\
pandemic covid-19. From this research, it was concluded that the 'state' endeavors in \\
this case the Bangkalan District Government and how to handle it in saving the \\
community from Covid-19 protesters with the representation of the pouring of the \\
community will cult a "holy text", noble values understood in pieces. regional law \\
products, both the Regent Regulation and the Regent's Decree. But the effort as a \\
good will of such authority is hindered by the simplicity of understanding and \\
interpretation of most of society's cult of a "sacred text", noble values understood in \\
pieces
\end{tabular}

\begin{tabular}{ll}
\hline Kata kunci: & Abstrak: \\
\hline "Teks Suci", Studi & Setahun lebih Pandemi COVID-19 melanda segala penjuru dunia, tak terkecuali \\
Filsafat, Kearifan & daerah-daerah terpencil di seluruh nusantara. Salah satu sebab tidak optimalnya \\
lokal, Covid-19 & upaya pemerintah dalam menghadapinya adalah ketidakpatuhan sebagian masyarakat \\
& pada beberapa aturan sudah dituangkan dalam bentuk produk hukum daerah. Tulisan \\
& ini bertujuan menganalisa serta mendalami ketidakpatuhan yang nyata dari \\
& masyarakat meski pemerintah daerah sudah berusaha maksimal untuk membuat \\
& masyarakatnya faham atas maksud dan tujuan mulia dari aturan tersebut. Dengan \\
& menggunakan studi literature dalam menganalisa atas fenomena empirik perilaku di \\
& kalangan masyarakat kabupaten Bangkalan dalam menyikapi kebijakan 'negara' \\
& dalam menghadapi pandemic covid-19. Dari penelitian ini mendapatkan kesimpulan \\
& bahwa ikhtiar yang dilakukan 'negara' dalam hal ini Pemerintah Daerah Kabupaten \\
& Bangkalan dan cara menanganinya dalam menyelamatkan masyarakat dari pendemi \\
& Covid-19 masih belum maksimal. Karena upaya good will dari otoritas tersebut \\
& terhalang oleh kesederhanaan pemahaman dan interpretasi dari sebagian besar \\
& masyarakat akan kultusnya sebuah "teks suci", nilai-nilai luhur yang dipahami masih \\
& sepenggal.
\end{tabular}

Received: May 03, 2021. Revised: June 08, 2021. Accepted: June 27, 2021

\section{Pendahuluan}

Ketika sebagian manusia dicekam oleh wabah penyakit yang mematikan, komunitas manusia tidak dapat mengelak dari pengalaman kekhawatiran. Kecemasan menjadi semacam pengalaman subyektif yang menjadi ruang lingkup hidup manusia (Riyanto, 2018). Setahun sudah WHO 
mengumumkan bahwa Covid 19 adalah pandemi. Pandemi yang harus disikapi sebagai sebuah ancaman kehidupan bagi semua umat manusia di seluruh dunia. Semua negara terdampak, tidak terkecuali Indonesia, melalui kekuasaannya lantas melakukan berbagai rekayasa sosial untuk mencegah penyebaran yang lebih luas dan berlanjut dengan peraturan-peraturan yang diundangkan. Kementerian-kementerian lantas mengeluarkan kebijakan sesuai urusan ketatanegaraan masingmasing berupa aturan-aturan dan larangan-larangan yang pada prinsipnya adalah penormaan nilai-nilai hukum dalam bentuk aturan-aturan yang dipaksakan kepada masyarakat untuk terciptanya tatanan yang lebih terarah dan terpadu dalam menghadapi pendemi.

Semua daerah baik provinsi maupun kabupaten/kota termasuk Kabupaten Bangkalan dalam penyelenggaraan otonominya, lantas "semacam diwajibkan" untuk melakukan rekayasa-rekayasa sosial sesuai wewenang di daerahnya masing-masing. Pengaturan instrumen hukum lantas diterapkan dalam wujud yang serupa meski tidak sama. Cepatnya penyebaran menuntut pula kecepatan pemerintah untuk mengambil tindakan pencegahan. Belum usai satu urusan kementerian ditindaklanjuti dalam bentuk aturan di daerah sudah menyusul kementerian lain menggelontorkan aturan baru yang secara hukum ketatanegaraan tetap perlu diakomodir dan diundangkan sebagai sebuah kebijakan di daerah.

Apakah hal tersebut kemudian memunculkan pengaturan yang signifikan dan menyeluruh di segala bidang terhadap masyarakat di semua daerah? Jawabannya tentu tidak! Perlombaan kecepatan bukanlah alur yang tepat bagi perumusan peraturan di daerah karena terbentur dengan mekanisme "pakem" pembuatan produk hukum. Mekanisme terstruktur sudah diamanahkan dalam peraturan perundang-undangan agar produk hukum yang dihasilkan memperoleh legitimasi dan tidak cacat secara proses hukum. Mekanisme itu sudah diatur secara jelas mulai hal-hal yang bersifat makro dalam Undang-Undang Nomor 12 Tahun 2011 tentang Pembentukan Peraturan Perundang-Undangan berikut peraturan-peraturan pelaksanaannya sampai pada langkah-langkah detail perumusan berupa tahapan-tahapan yang harus ditempuh sebagaimana diatur dalam Peraturan Menteri Dalam Negeri Nomor 80 Tahun 2015 tentang Pembentukan Produk Hukum Daerah beserta perubahannya yaitu Peraturan Menteri Dalam Negeri Nomor 120 Tahun 2018.

Sinkronisasi dan harmonisasi aturan yang menjadi ciri khas dan tuntutan dalam pembuatan sebuah produk hukum terkadang harus dikorbankan demi terciptanya pencegahan penyebaran pendemi ke pelosok-pelosok daerah. Dan yang terjadi selanjutnya tak ubahnya penyeragaman aturan di perbagai daerah padahal kita akui bersama bahwa tiap daerah di Indonesia memiliki karakteristik masyarakat yang berbeda. Kecepatan pembuatan aturan di daerah kemudian banyak menjadi alasan utama ditinggalkannya nilai-nilai kearifan lokal yang semestinya menampung karakteristik sosial masyarakat setempat. Seluruh nusantara dari sabang sampai merauke dari kota-kota besar sampai ke pelosok-pelosok pedesaan kemudian dipaksa untuk melakukan cara yang sama, yang dianggap paling efektif oleh negara, dalam menghadapi pandemi. Dan cara tersebut adalah "pembatasan interaksi sosial" dengan bentuk dan istilah apapun dalam hirarki perundang-undangan di seluruh Indonesia.

Dapat ditebak apa yang terjadi selanjutnya ketika aturan yang dibuat dengan cara seperti diatas, dan dalam waktu yang sesingkat-singkatnya harus diterapkan pada masyarakat yang karakternya beragam. Hasilnya pastilah bahwa peraturan tersebut gagal dipahami karena minimnya waktu untuk sosialisasi, peraturan tersebut berhasil sedikit dipahami tapi tidak dipatuhi atau bahkan peraturan tersebut sudah betul-betul dipahami tapi sudah tidak efektif lagi.

Kajian kali ini tidak akan membahas kegagalan masyarakat dalam memahami aturan, karena hal tersebut adalah celah yang seharusnya sudah dapat diprediksi dari awal akan terjadi, mengingat "noda" dalam proses perumusan yang telah disampaikan pada paragraf sebelumnya. Begitu pula rasanya juga tidak perlu dibahas bagaimana peraturan tersebut menjadi tidak efektif lagi karena pencegahan penyebaran justru baru difahami setelah covid-19 telah terlanjur menyebar sampai ke seluruh pelosok perdesaan di daerah. Kajian ini ditujukan untuk mendalami dan menemukan jawaban atas sisi 
ketidakpatuhan yang nyata dari masyarakat meski pemerintah daerah sudah berhasil membuat masyarakatnya sedikit faham atas maksud dan tujuan mulia dari aturan tersebut.

\section{Metode Penelitian}

Penelitian dilakukan melalui studi literatur dengan pendekatan analisis deskriptif atas fenomena yang terjadi. Selain menganalisis perilaku masyarakat Bangkalan dan cara menanganinya, penelitian ini juga menyajikan tinjauan pustaka terhadap beberapa literatur yang relevan dengan penelitian ini. Dalam dialektika Metode penelitian yang digunakan dalam penelitian ini adalah studi pustaka dengan pendekatan analisis deskriptif.

Data-data resmi diperoleh dari instansi Pemerintah Kabupaten Bangkalan. Data yang telah terkumpul kemudian dianalisis untuk mendapatkan informasi, namun terlebih dahulu data tersebut dipilih berdasarkan reliabilitasnya (Mantra, 2004). Yang dimaksud analisis adalah serangkaian upaya sederhana tentang bagaimana data penelitian pada gilirannya dikembangkan dan diproses menjadi kerangka kerja sederhana (Zed, 2008). Dengan berpijak pada framework elaborasi filosofis dalam Buku Relasionalitas: Aku, Teks, Liyan dan Fenomen, penulis mencoba untuk menjawab permasalahan penelitian yang telah dikemukakan pada bagian Latar Belakang di atas. Penulis mencoba menyelami lebih mendalam lagi tentang realitas apa yang sebenarnya terjadi sehingga menyebabkan ketidakpatuhan masyarakat Bangkalan terutama suku madura asli terhadap aturan pemerintah daerah tentang Protokol Kesehatan dalam Pandemi Covid-19 sejauh ini.

\section{Pembahasan dan Diskusi}

\section{a. Kondisi Covid-19 di Kabupaten Bangkalan}

Melihat perkembangan kasus positif yang ada di Bangkalan kami memanfaatkan data yang dimiliki pemerintah kabupaten kota Bangkalan dari berbagai media. Diantaranya terkait perkembangan sejak dari awal ditetapkannya Covid-19 sebagai pandemi sampai awal April 2021 dapat dilihat dari grafik dibawah ini:

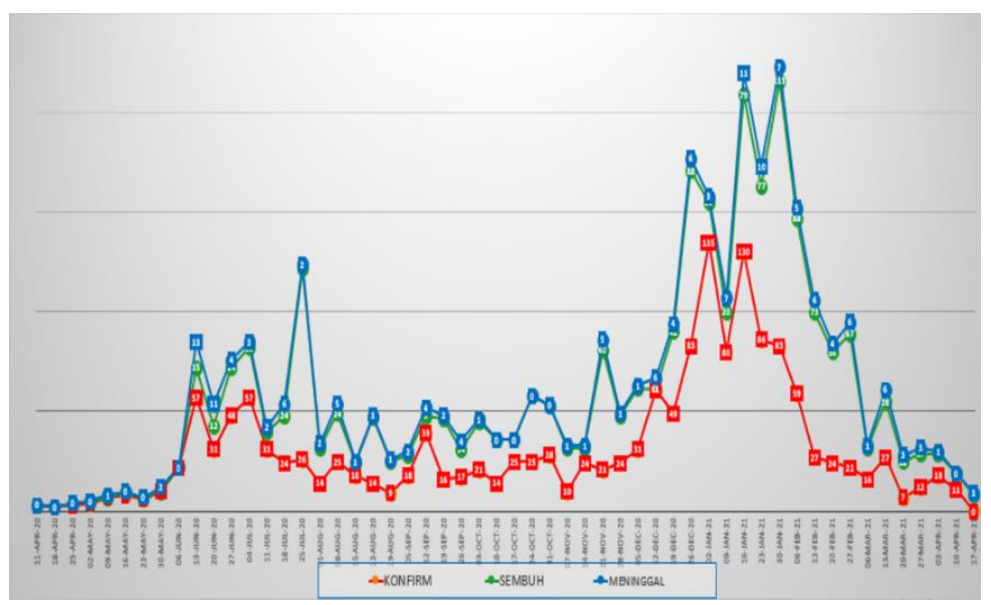

Gambar 1. Grafik Kurva Covid-19 dari Dinas Kesehatan Kab Bangkalan

Melihat grafik kurva di atas dijelaskan oleh Dinas Kesehatan Kabupaten Bangkalan bahwa kasus Covid-19 pada beberapa bulan terakhir telah mengalami penurunan kasus yang signifikan, namun zona Kabupaten Bangkalan sempat mengalami perubahan dari kuning menjadi orens, hal ini disebabkan karena adanya peningkatan jumlah kematian yang awalnya $9 \%$ menjadi $10 \%$.

Data lain yang diperoleh dari sumber yang sama yakni Dinas Kesehatan Kabupaten Bangkalan pada Tanggal 12 April 2021 dapat dilihat pada tabel dibawah ini: 


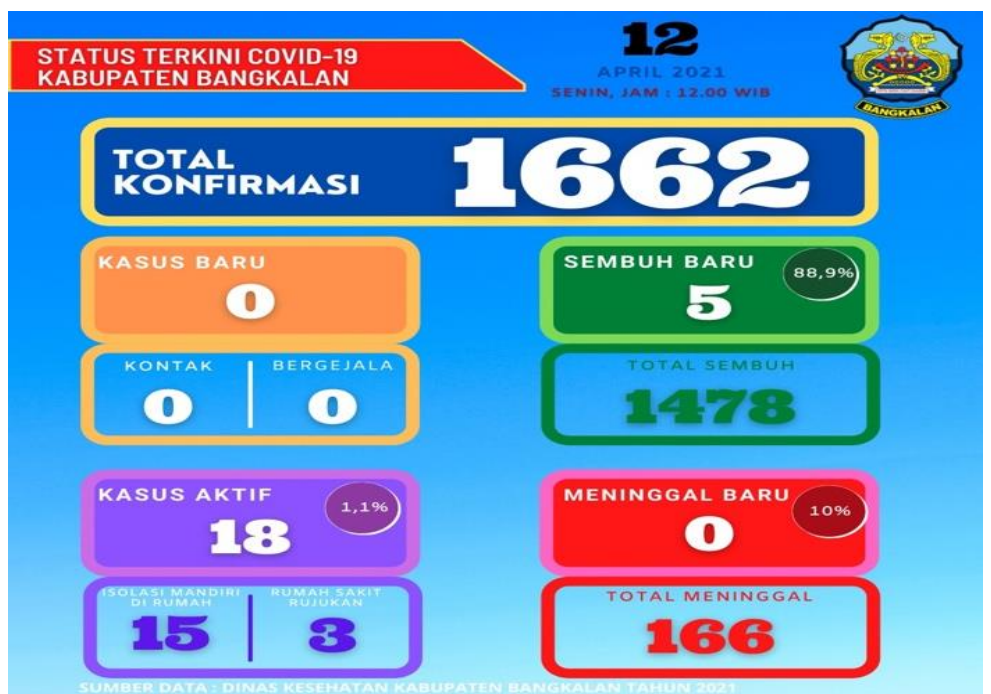

Gambar 2. Status Terkini Covid-19 dari Dinas Kesehatan Kab Bangkalan

Update terbaru pada tanggal 21 April 2021 sebagaimana dilansir pada situs resmi Pemerintah Kabupaten Bangkalan, http://www.bangkalankab.go.id tentang sebaran pada tiap kecamatan di seluruh wilayah Kabupaten Bangkalan dapat dilihat pada peta dibawah ini:

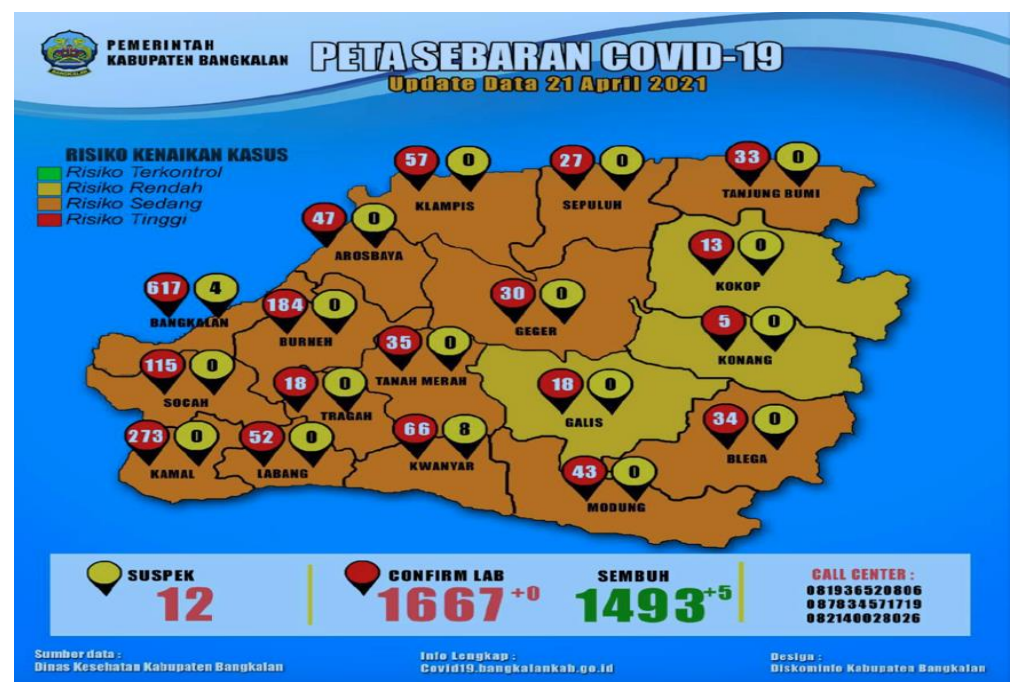

Gambar 3. Peta Sebaran Covid-19 di Kabupaten Bangkalan

Dari data-data diatas dapat terlihat bahwa Covid-19 telah menyebar secara signifikan ke seluruh pelosok daerah di Kabupaten Bangkalan. Angka tersebut harus diakui adalah data pasien Covid-19 dan bukannya jumlah masyarakat yang terpapar oleh virus Covid-19. Mengapa demikian? Karena sebaran Covid-19 yang "unik" dengan beberapa kategori penderita telah menyebabkan sebagian orang yang terpapar Covid-19 tidak dapat didata, kelompok tersebut adalah para "Orang Tanpa Gejala" atau yang dalam peristilahan terakhir telah berubah nama sesuai Keputusan Menteri Kesehatan Nomor HK.01.07/Menkes/ 413/2020 tentang Pedoman Pencegahan dan Pengendalian Coronavirus Disease 2019 (Covid-19).

\section{b. Upaya Rekayasa Sosial Melalui Peraturan Perundang-Undangan}

Berdasar data produk hukum daerah yang secara resmi dirilis oleh Bagian Hukum Pemerintah Daerah Kabupaten Bangkalan pada situs http://jdih.bangkalankab.go.id telah diperoleh beberapa produk hukum daerah yang secara khusus mengatur masyarakat Bangkalan dalam menghadapi pandemi Covid-19: 
Pertama, adalah Peraturan Bupati Bangkalan Nomor 46 Tahun 2020 tentang Percepatan Pencegahan dan Penanganan Corona Virus Disease 2019 (Covid-19) di Kabupaten Bangkalan. Dalam perkembangannya untuk memberikan penekanan kepatuhan kepada masyarakat, peraturan ini dilakukan perubahan dengan menekankan sanksi atas ketidakpatuhan tersebut. Perubahan tersebut tertuang dalam Peraturan Bupati Bangkalan Nomor 63 Tahun 2020.

Peraturan diatas dibuat bukan hanya sebagai tindak lanjut atas kebijakan Pembatasan Sosial Berskala Besar yang telah ditentukan oleh Pemerintah (pusat) namun lebih merupakan penormaan di daerah dari berbagai aturan-aturan dari kementerian untuk penanggulangan penyebaran Covid-19 di Kabupaten Bangkalan. Namun jika kita sandingkan dengan lonjakan data pandemi setelah diundangkannya peraturan tersebut sejak tanggal 26 juni 2020, sebagaimana terlihat pada Data 1 : Grafik Kurva Covid-19 justru malah terjadi lonjakan penderita. Hal tersebut menunjukkan ketidakefektifan dari peraturan tersebut meskipun dalam perkembangannya masih dilakukan perubahan dengan memasukkan sanksi dalam Peraturan Bupati Nomor 63 Tahun 2020 yang diundangkan pada Tanggal 19 Agustus 2020, peraturan tersebut tetap tidak efektif. Lonjakan kasus Covid-19 malah terlihat begitu signifikan pada akhir Tahun 2020 sampai awal Tahun 2021.

Kedua, penetapan Keputusan Bupati tentang Pemberlakuan Pembatasan Kegiatan Masyarakat Berbasis Mikro dan Pembentukan Posko Penanganan Corona Virus Disease 2019 di Tingkat Desa dan Kelurahan Untuk Pengendalian Penyebaran Corona Virus Disease 2019 (Covid-19) di Kabupaten Bangkalan. Penetapan Keputusan Bupati merupakan tindak lanjut dari Penetapan secara nasional yang dilakukan oleh Pemerintah pusat. Dalam perkembangannya Keputusan ini terus dilakukan perpanjangan secara berkala dan sampai kajian ini dibuat perpanjangan tersebut belum juga usai. Hal tersebut menunjukkan bahwa Keputusan ini pun belumlah terlalu memberikan penanganan yang optimal.

Selain dua produk hukum yang penulis coba angkat diatas, masih banyak lagi aturan-aturan, sebut saja pembentukan Gugus Tugas dan Satuan Tugas Covid-19 serta produk hukum lainnya yang menunjukkan upaya maksimal dari Pemerintah Daerah.

\section{c. Ruang Kulturalis-Religiusitas Masyarakat Bangkalan}

Dister menjelaskan bahwa religiusitas adalah suatu keadaan di mana individu merasakan dan mengakui adanya kekuatan tertinggi yang menaungi kehidupan manusia dan hanya kepada-nya saja manusia bergantung dan berserah diri. Semakin seseorang mengakui adanya Tuhan maka semakin tinggi religiusitasnya. Glock dan Stark mengatakan bahwa, religiusitas adalah keberagamaan yang menunjukkan ketaatan dan komitmen seseorang terhadap agamanya. Ciri-ciri individu yang mempunyai religiusitas tinggi dapat dilihat dari tindak-tanduk, sikap dan perkataan, serta seluruh jalan hidupnya mengikuti aturan-aturan yang diajarkan oleh agama (Nurul, 2018).

Berbagai penelitian sebelumnya yang telah banyak dilakukan untuk menemukan kultur budaya masyarakat Bangkalan sebagai bagian dari masyarakat madura, menunjukkan bahwa tingginya nilainilai religius dalam kehidupan sehari-hari. Keseharian kehidupan masyarakat tersebut banyak dipengaruhi oleh nilai-nilai agama islam dan apabila lebih dipersempit lagi pengaruh terbesar adalah pemahaman ala Nahdhotul Ulama (NU) sebagai sebuah organisasi islam terbesar. "Lifting Madura in the discussion of $N U$ is like sorting the sugar out of it's sweetness"(Hamdi, 2013). Tradisi-tradisi keNU-an adalah kehidupan sehari-sehari masyarakat.

Secara umum religiusitas masyarakat etnis Madura telah dikenal luas berpegang teguh pada tradisi dan ajaran Islam dalam menapak realitas kehidupan sosial budayanya. Akan tetapi representasi religiusitas (identitas keagamaan) ini belum sepenuhnya diterapkan dalam perilaku masyarakat Madura. Perilaku konsumsi masyarakat Madura adakalanya belum sesuai dengan prinsip Islam. Perilaku konsumsi yang seharusnya didominasi oleh motif maslahah, kebutuhan, dan 
kewajiban terkadang masih dipengaruhi oleh ego, rasionalisme (materialisme), dan keinginankeinganan yang bersifat individualistis (Nurul, 2017).

Kultur yang seperti ini menimbulkan sebuah pemahaman tersendiri bagi masyarakat tentang makna bahkan lebih dalam lagi kalau boleh disebut sebagai hakikat dari hidup. Hidup hanya bermakna apabila selaras, menyatu dengan agama. Agama adalah pedoman, agama adalah peraturan, agama adalah "bahasa" bagi yang hidup. Agama lantas diatribusikan sebagai pemegang "hak paten" atas kebenaran hidup manusia, bahkan juga - menurut kepercayaan yang ada - kebenaran sesudah hidup di dunia ini. Diluar kebenaran itu, tidak boleh ada yang mengambil posisi rivalitas. Setiap opini kebenaran yang lain adalah salah atau sesat. Jadi disini berlaku absolutisme kebenaran agama. (Riyanto, 2018).

Paradigma seperti itu kemudian membawa cara penyikapan yang khas dari masyarakat Bangkalan atas sebuah peraturan yang munculnya bukan berasal dari sisi agama, yang seakan menjadi "rival" dari aturan-aturan agama yang selama ini diyakini kebenarannya. Tak terkecuali aturan-aturan dari pemerintah dan/atau pemerintah daerah, dalam bahasan ini adalah aturan-aturan tentang pencegahan Covid-19 sebagaimana telah disebutkan pada bagian sebelumnya di atas. Masyarakat Bangkalan akan "mempertanyakan" kesesuaian dari aturan-aturan tersebut dengan nilai-nilai dalam ajaran agama, sebelum mereka "memutuskan" untuk patuh atau tidak.

Selain hal tersebut diatas, nilai-nilai religius masyarakat juga membawa arah dan cara kepatuhan tersendiri, masyarakat lebih patuh pada kiai. Kepatuhan Masyarakat pada kiai tersurat dalam ungkapan umum bahwa "ayamnya saja masih dianggap guru apalagi anaknya". Kepatuhan terhadap tokoh informal semacam ini terkadang berakibat buruk, yakni tidak efektif suatu perundangundangan. (Shomad, 2017).

\section{d. “Teks Suci” dalam Perspektif Masyarakat Bangkalan}

Agama mengajarkan mengenai moral. Moral untuk berinteraksi dengan lingkungannya, antar manusia, manusia dengan makhluq lainnya, dan manusia dengan Tuhannya. Sehingga dalam agama apapun ajaran tentang "moral" adalah sama, namun manusia sebagai objek dari doktrin-doktrin agama tersebut memiliki perbedaan dalam menangkap makna-makna dari ajaran-ajaran tersebut. Artinya, rasa keberagamaan (religiusitas) tiap-tiap individu berlainan, tapi pada dasarnya setiap manusia itu memiliki rasa keberagamaan (religiusitas). Sehingga, tidak salah kalau masih ada orang yang "beragama" masih memiliki "moral" yang dalam pandangan manusia lainnya adalah kurang baik dan menyimpang dari aturan yang telah ditentukan (Fauzan, 2009).

Al-Quran dan Hadits serta fatwa-fatwa ulama dalam kitab-kitab kuning yang diperoleh baik dalam proses pendidikan sejak kecil di madrasah atau pesantren maupun yang didapat dari pengajianpengajian setelah dewasa, menjadi pedoman bagi masyarakat dalam menjalani kehidupan sehari-hari. Lantas "dalil-dalil" keagamaan sebagai sebuah "Teks Suci" kemudian memegang peranan penting dalam menentukan arah perilaku masyarakat.

Disini penulis mencoba menyuguhkan sebagian kecil dalil yang telah dianggap sebagai "Teks Suci" oleh sebagian masyarakat. Sebagaimana telah diriwayatkan bahwa Rasulullah SAW sangat menekankan arti pentingnya sebuah silaturrahmi. Beberapa Hadits telah diriwayatkan oleh para perawi hadits terkemuka, diantaranya:

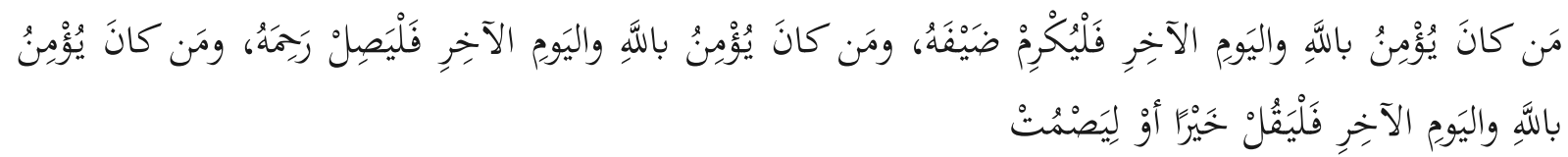

"Barangsiapa beriman kepada Allah dan hari Akhir, hendaknya ia memuliakan tamunya, dan barangsiapa beriman kepada Allah dan hari Akhir, hendaknya ia menyambung tali silaturrahmi, dan barangsiapa beriman kepada Allah dan hari Akhir, hendaknya ia berkata baik atau diam".(Bukhari, 2019). 


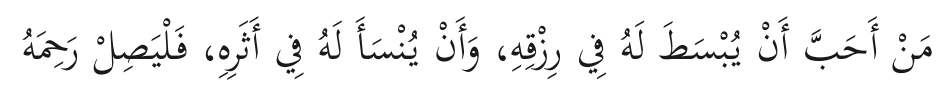

"Barang siapa ingin dilapangkan rezekinya dan ditambah umurnya, maka hendaklah menjalin silaturrahim."(Bukhari, 2019)

Dalam riwayat lain, Abu Dawud RA juga meriwayatkan sebuah Hadits tentang pentingnya Silaturrahmi:

$$
\text { قالَ اللَّه: أَنا الرَّمنُ وَهيَ الرَّحمُ، شَقَقتُ لَها اسمًا من اسمي، من وصلَها وصلتُهُ، ومن قطعَها بتتُّهُ }
$$

"Allah berfirman, "Aku adalah Maha Pengasih dan ia adalah Rahim, nama itu diambil dari bagian nama-Ku, siapa yang menyambungnya, maka Aku memberikan rahmat-Ku kepadanya, dan siapa yang memutuskannya, maka Aku memutuskan rahmat-Ku darinya."(Al-Asqalani, n.d.)

Berpegang pada dalil-dalil diatas telah menciptakan pemahaman pada masyarakat bahwa silaturrahmi adalah sebuah keniscayaan untuk dilakukan. Berkunjung dan berkumpul bersama dalam suasana kekeluargaan ke rumah saudara atau bahkan "sowan" dan "sungkem" ke kiai pada hari baik (termasuk diantaranya dua hari besar yakni Idhul Fitri dan Idhul Adha) bagi masyarakat Bangkalan adalah sebuah keniscayaan yang tidak boleh ditinggalkan. Mereka akan merasa bersalah bahkan berdosa apabila tidak melakukannya.

Disinilah bertemunya dua aturan berbeda yang bahkan secara hirarki peraturan perundangundangan pun tidak bisa disandingkan dan dibandingkan. Disatu sisi anjuran silaturrahmi adalah sebuah aturan yang bersifat dogmatis bagi masyarakat sedangkan di sisi lain untuk menjaga kesehatan, pemerintah daerah telah membatasi ruang gerak baik melalui kebijakan Pembatasan Sosial Berskala Besar (PSBB) maupun Pemberlakuan Pembatasan Kegiatan Masyarakat (PPKM) Skala Mikro yang terus diperpanjang sampai kajian ini dibuat.

Fenomena lain yang patut juga untuk diperhatikan adalah perihal sholat berjemaah di masjid. Aturan pemerintah untuk menjaga jarak sebagai penerapan protokol kesehatan juga termentahkan dengan dalil bahwa shaf sholat harus lurus dan rapat sebagaimana telah disabdakan oleh Rasulullah SAW bersabda:

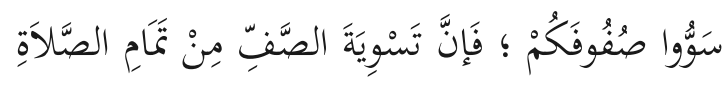

“Luruskanlah shaf-shaf kalian, karena lurusnya shaf termasuk kesempurnaan shalat."(Muslim, 2019)

Sebagian masyarakat telah mengartikan bahwa perintah dalam hadits diatas tidak hanya meluruskan shaf ketika sholat berjemaah tapi juga merapatkan shaf, meskipun dapat kita ketahui bahwa Rasulullah SAW tidak mengatakan, "Renggangkanlah diantara kaki-kaki kalian!” Beliau juga tidak mengatakan, "Tempelkanlah pundak dengan pundak juga tumit dengan tumit." Akan tetapi para Sahabat melakukan itu, mereka menempelkan pundak mereka dengan pundak Sahabat di sampingnya sebagai realisasi dari perintah Rasul, "Sejajarkanlah pundak-pundak kalian!”.

Fenomena ini terlihat jelas di beberapa masjid atau surau yang menyelenggarakan sholat berjemaah mulai dari sholat 5 waktu, sholat Jumat atau bahkan sholat tarawih pada bulan suci ramadhan baik ramadhan tahun lalu maupun di tahun kali ini. Terlihat betapa ada pengabaian atas aturan pemerintah untuk menjaga jarak.

Pada awal-awal pandemi, pihak Nahdhotul Ulama sendiri telah melakukan kajian dalam bentuk Bahtsul Masa'il. Berangkat dari pemikiran para fuqahô' atau ahli fiqih memahami bahwa perintah dalam hadits tersebut adalah perintah sunnah, bukan perintah wajib. Artinya tindakan merenggangkan shaf sebagai kebalikan dari upaya merapatkan shaf yang diperintahkan bukan keharaman, melainkan makruh. Status makruh pada masalah ini adalah makruh yang ringan, bukan yang berat ( مكروه كراهة غير شديدة). Fuqahā muta'akhkhirīn menamakan makruh jenis ini dengan khilāful awlā, yakni suatu 
larangan yang tidak memiliki acuan dalil secara langsung melainkan larangan yang digali atau dipahami dari perintah sunnah. Oleh karena itu disimpulkan bahwa kerapatan shaf bukan merupakan syarat sah shalat berjamaah, melainkan syarat untuk mendapatkan keutamaan shalat berjamaah. Bahkan, menurut sebagian pendapat, kerapatan shaf itu hanya menjadi syarat untuk mendapatkan keutamaan shaf sebagaimana keterangan pada I'anatut Thalibin, Hasyiyatul Qaliyubi, dan Hawasyis Syarwani wal Abbadi. (islam.nu, 2020).

Namun, bagaimanapun upaya dilakukan baik oleh pemerintah maupun organisasi keagamaan seperti Nahdhotul Ulama' dengan melakukan sosialisasi atas protokol kesehatan, tetap saja sulit untuk memberikan perspektif baru bagi masyarakat atas pemahaman terhadap "teks suci" yang sudah terlanjur dijadikan kebiasaan dan budaya. Kegiatan-kegiatan sosial pun berjalan seperti biasanyanya tanpa adanya protokol keseatan yang menjadi aturan pemerintah, misal walimah nikah, kirim doa, perdagangan, hajatan, dll. Serta di tempat-tempat tertentu masyarakat melakukan cara sholat berjemaah dengan shaf yang rapat. Bahkan ada kecenderungan untuk mengisi sela-sela shaf yang terlihat masih belum rapat.

\section{e. Keberlakuan Sosiologis}

Menyimak data dan fenomena pada masyarakat sebagaimana telah diuraikan di atas, maka pertanyaan selanjutnya bukan sebatas efektif atau tidak peraturan-peraturan protokol kesehatan tersebut dalam penerapannya pada masyarakat Bangkalan, akan tetapi hendaklah lebih mendalam lagi. Dalam penjelasan Pasal 81 Undang-Undang Nomor 12 Tahun 2011 tentang Peraturan Perundangundangan disebutkan bahwa "Dengan diundangkannya Peraturan Perundang-undangan dalam lembaran resmi sebagaimana dimaksud dalam ketentuan ini, setiap orang dianggap telah mengetahuinya". Inilah yang disebut Fiksi Hukum yaitu asas presumptio iures de iure. Semua orang dianggap tahu hukum, tak terkecuali petani yang tak lulus sekolah dasar, atau warga yang tinggal di pedalaman. Dalam bahasa Latin dikenal pula adagium ignorantia jurist non excusat, ketidaktahuan hukum tidak bisa dimaafkan. Seseorang tidak bisa mengelak dari jeratan hukum dengan berdalih belum atau tidak mengetahui adanya hukum dan peraturan perundang-undangan tertentu. (Hukumonline, 2021).

Disini perlu dikemukakan perihal teori keberlakuan hukum secara sosiologis sebagaimana telah disampaikan oleh Prof. Jimly Asshiddiqie (2014). Pandangan sosiologis mengenai keberlakuan ini cenderung lebih mengutamakan pendekatan yang empiris, suatu norma hukum baru dapat dikatakan berlaku secara sosiologis apabila norma hukum dimaksud memang berlaku menurut salah satu kriteria, yaitu: Pertama, Kriteria Pengakuan (recognition theory) menyangkut sejauh mana subjek hukum yang diatur memang mengakui keberadaan dan daya ikat serta kewajibannya untuk menundukkan diri terhadap norma hukum yang bersangkutan. jika subjek hukum yang bersangkutan tidak merasa terikat, maka secara sosiologis norma hukum yang bersangkutan tidak dapat dikatakan berlaku baginya. Kedua, Kriteria penerimaan (reception theory) pada pokoknya berkenaan dengan kesadaran masyarakat yang bersangkutan untuk menerima daya-atur, daya-ikat, dan daya-paksa norma hukum tersebut baginya. Ketiga, Kriteria faktisitas hukum. sejauh mana norma hukum itu sendiri memang sungguh-sungguh berlaku efektif dalam kehidupan nyata masyarakat. meskipun suatu norma hukum secara yuridis formal memang berlaku, diakui (recognized) dan diterima (received) oleh masyarakat sebagai suatu yang memang ada (exist) dan berlaku (valid), tetapi dalam kenyataan praktiknya sama sekali tidak efektif, berarti dalam faktanya norma hukum itu tidak berlaku.

\section{Kesimpulan}

Berbagai upaya telah dilakukan secara maksimal oleh Pemerintah termasuk Pemerintah Daerah Kabupaten Bangkalan dalam upaya untuk menyelamatkan masyarakat dari pendemi Covid-19. Upayaupaya tersebut merupakan kebijakan-kebijakan yang di Kabupaten Bangkalan dituangkan dalam 
bentuk produk hukum daerah, baik Peraturan Bupati maupun Keputusan Bupati. Namun segala good will dari otoritas tersebut terhalang oleh kesederhanaan pemahaman dari sebagian masyarakat akan kultusnya sebuah "teks suci", nilai-nilai luhur yang dipahami sepenggal.

Realitas ini hanyalah sebuah contoh kecil dan seharusnya tidak membuat kita melihat dari sisi tumpulnya hukum saja, atau bahkan pula tidak lantas membuat kita hanya melihat dari sisi ketidakpatuhan masyarakatnya. Tapi mari kita tilik lebih dalam lagi bahwa apa yang sebenarnya terjadi adalah sebuah ketidaktepatan tool terhadap obyeknya. Lebih arif kalau kita tidak menyalahkan proses perumusan kebijakan maupun kurangnya sosialisasi semata, tapi sebaiknya kita lihat sebagai sebuah kekurangfahaman pembuat kebijakan atas kondisi sosiologis masyarakatnya. Ada kearifan lokal yang tertanggal dan tertinggal dalam upaya tersebut. Nilai-nilai lakolitas dan kedaerahan sebaiknya tidak disimak sebagai yang mengerdilkan atau menyempitkan, melainkan malah mengayakan, meluaskan, dan mengaktualisasikan cakrawala pengertian nilai-nilai Pancasila. Oleh karena itu, penting sekali untuk menggali dan mendalami "filsafat Keindonesiaan" sebelum pemerintah (pusat) terutama pemerintah daerah melalui otonominya menerapkan sebuah kebijakan. Dimana "filsafat Keindonesiaan" digali? Di dalam pengalaman hidup sehari-hari manusiamanusianya; di dalam tradisi-historis-kultural-religius-sosial-natural yang dihidupi oleh masyarakat; di wilayah-wilayah pinggiran kepulauan Nusantara termasuk yang terpencil, miskin, pedalaman nun jauh di hutan-hutan belantara atau malah peta geografisnya pun kerap tidak dikenal.

\section{Daftar Pustaka}

Al-Asqalani, I. H. (n.d.). Bulughul Maram. Jabal.

Asshiddiqie, J. (2014). Perihal Undang-Undang. Rajawali Perss.

Adhim, Fauzan (2009). Pengaruh Religiusitas Terhadap Prestasi Kerja Pegawai Alumni Dan Bukan Alumni Pesantren (Studi pada Kantor Depag Kabupaten Bangkalan). MODERNISASI, Volume 5, Nomor 2, Juni.

Bukhari, I. (2019). Shahih Al Bukhari. Pustaka As-Sunah.

Hamdi, A. Z. (2013). Radicalizing Indonesian moderate islam from within: The NU-FPI relationship in Bangkalan, Madura. Journal of Indonesian Islam, 7(1), 71-95. https://doi.org/10.15642/JIIS.2013.7.1.71-95

Hasan, Nurul Fatma. (2018). Religiusitas dan perilaku konsumsi perspektif islam (studi pada masyarakat perantau madura). The 3 rd Annual International Conference on Islamic Education

Mantra, I. B. (2004). Filsafat Penelitian dan Metode Penelitian Sosial. Pustaka Pelajar.

Muslim, I. (2019). Shahih Muslim. Pustaka As Sunnah.

Riyanto, A. (2015). Kearifan Lokal PANCASILA; Butir-Butir Filsafat Keindonesiaan. Kanisius.

Riyanto, A. (2013) Menjadi Mencintai: Berfilsafat Teologis Sehar-hari. PT Kanisius

Riyanto, A. (2018). Relasionalitas, Filsafat Fondasi Interpretasi: Aku, Teks, Liyan, Fenomen. PT Kanisius.

Shomad, A. (2017). HUKUM ISLAM Penormaan Prinsip Syariah Dalam Hukum Indonesia. Kencana.

Zed, M. (2008). Metode Penelitian Kepustakaan. Yayasan Obor Indonesia.

https://www.hukumonline.com/berita/baca/hol19115/fiksi-hukum-harus-didukung-sosialisasihukum-/ (Diakses pada 24 April 2021Pukul 21:29)

https://islam.nu.or.id/post/read/120666/hukum-merapatkan-shaf-pada-shalat-berjamaah-di-masacovid-19 (Diakses pada 23 April 2021Pukul 22:29) 